\title{
Mamãe eu quero: Carmen Miranda's Maternal Abundance
}

Sean Griffin'

1. Sean Griffin é professor de Cinema-Televisão na Universidade Southern Methodist de Dallas, Texas. É autor de Tinker Belles and Evil Queens: The Walt Disney Company from the Inside Out e co-autor (com Harry M. Benshoff) de America on Film: Representing Race, Class, Gender and Sexuality at the Movies and Queer Images: A History of Gay and Lesbian Film in America. Possui também artigos sobre os musicais da 20th Century-Fox publicados no Cinema Journal e na obra The Irish in Us: Irishness, Performativity, and Popular Culture. 


\section{Resumo}

Na resenha do segundo filme estrelado por Carmen Miranda em Hollywood, Uma noite no Rio (That Night in Rio, 1941), a revista Variety assinalou de que maneira sua presença como coadjuvante claramente roubava a cena dos supostos protagonistas: “[Don] Ameche está correto em seu duplo papel, e Miss [Alice] Faye está muito atraente, mas é a tempestuosa Miranda que dispara na frente, desde a primeira sequência". Esse tipo de comentário parece indicar certa surpresa com o fato de que Carmen, estando em terceiro lugar nos créditos, aparecesse de forma tão central já no início do filme. Efetivamente, todos os três primeiros filmes que Carmen fez para a 20th Century Fox em Hollywood abrem com um número musical seu, antes que qualquer fala fosse pronunciada. Este formato em comum apresenta Carmen para o público sem um nome de personagem, sem um foco narrativo ou (como discutirei adiante) forte marcação de espaço e tempo. De outro modo, essas aberturas enfatizam Carmen como força central e dominante - seu corpo com elaborados acessórios e movimentos, seu desempenho vocal único e, de muitas maneiras, seu mundo.

\section{Palavras-chave}

Carmen Miranda, narrativa de filmes musicais, políticas de representação. 


\section{Abstract}

In reviewing Carmen Miranda's second Hollywood picture That Night in Rio (1941),Variety pointed out how Miranda's ostensibly supporting character upstaged the supposed leads: "[Don] Ameche is very capable in a dual role, and Miss [Alice] Faye is eye-appealing but it's the tempestuous Miranda who really gets away to a flying start from the first sequence." Such a comment might seem to indicate a sense of surprise that third-billed Miranda would be placed so centrally at the very start of the film. Yet, all three of her first films for Hollywood studio $20^{\text {th }}$ CenturyFox open with Miranda performing a musical number before a line of dialogue has been uttered. This common motif presents Miranda to the audience unfettered by a fictional character's name, any sense of narrative or (as will be discussed) even a strong sense of space and time. Rather, such openings stress Miranda as central dominating force-her body in all its elaborate adornment and motion, her unique vocal delivery, and in many ways, her world.

\section{Keywords}

Carmen Miranda, musical film narrative, politics of representation 
In reviewing Carmen Miranda's second Hollywood picture That Night in Rio (1941), Variety pointed out how Miranda's ostensibly supporting character upstaged the supposed leads: "[Don] Ameche is very capable in a dual role, and Miss [Alice] Faye is eye-appealing but it's the tempestuous Miranda who really gets away to a flying start from the first sequence" (Mar. 7, 1941). Such a comment might seem to indicate a sense of surprise that third-billed Miranda would be placed so centrally at the very start of the film. Yet, all three of her first films for Hollywood studio $20^{\text {th }}$ Century-Fox open with Miranda performing a musical number before a line of dialogue has been uttered. This common motif presents Miranda to the audience unfettered by a fictional character's name, any sense of narrative or (as will be discussed) even a strong sense of space and time. Rather, such openings stress Miranda as central dominating force-her body in all its elaborate adornment and motion, her unique vocal delivery, and in many ways, her world.

Many critics of these "Good Neighbor" musicals (the term referring to the U.S. foreign policy during World War II that attempted to forge stronger ties to the Latin American region) assert that the films present Latin America as an Orientalist fantasyland by and for the patronizing gaze of U.S. characters and audiences. Ella Shohat and Robert Stam present an example of the usual critique of these films:

Latin Americans (and Afro-Americans) were almost invariably marginalized by the narrative and cinematic codes, and were usually limited to roles as entertainers within the musical numbers. The musical's disjunctive structure made possible an ethnic division of labor, counterpointing a relatively 'realistic' mode of narrative for the White characters against implausibly ludic musical numbers for the Latinos (SHOHAT \& STAM, 1994: 231).

Miranda's introductory performances in her first three Hollywood films seem to fit this critique, presenting her as an exotic Other for "white" U.S. consumption. 
Yet, these opening numbers are not anchored by an establishing point-of-view shot from the non-Latin characters-and in fact, there are never any reverse shots of some audience shown watching Miranda. Instead, Miranda herself dominates the screen - the camera (and hence the viewer) unable to turn away from her. Emphasizing this sense of control, Miranda's contract with Fox included a provision that forbade editors to cut away from her while she was singingeffectively blocking shots of a controlling gaze by the white protagonists. ${ }^{2}$

Consequently, these opening numbers arguably move from presenting Miranda as an object or exotic commodity to expressing her (and/or her characters') own subjectivity, inviting U.S. viewers (and others) into her environment and her embrace by enveloping the audience member with an excess of sight and sound. The sense of envelopment exemplifies theories of the cinematic apparatus as a recreation of the psychic sense of maternal plenitude often associated with Jacques Lacan's psychoanalytical concept of the Imaginary realm. This Imaginary realm, in which the individual has no sense of separation (or even sense of self) and thus no sense of want, is replaced at a certain point in an individual's development by entrance into the Symbolic realm, a state of consciousness defined by an awareness of lack, of boundaries and of one's place within a structured existence. Lacan theorized that those within the Symbolic continually strive to return to the Imaginary's sense of unity and abundance-a desire that I argue Miranda's opening numbers in these films activate.

This is not to deny the problematic and stereotypical manner in which Hollywood often presented Miranda. For example, filmmakers at Fox consistently failed to distinguish between various national cultures by placing Brazilian Miranda in Argentina, Cuba or other non-Portuguese speaking Latin American settings. The

2. Dorothy Hechtlinger, "Rings on Her Fingers" Conference with Mr. Zanuck on 1st Draft Continuity (Sept. 26 - 30, 1940), 3, University of Southern California Fox Script Collection, reports that "Mr. Zanuck pointed out that you cannot cut away from Miranda once she starts to sing." (underlined in the original) "Rings on Her Fingers" would eventually be retitled That Night in Rio. 
same aspects that suggest a return to the Imaginary also function as a reductive, simplistic image of Latin America as a vacation playland free from want or care, without its own sociopolitical or economic complexities (and without any resistance to U.S. imperialism). Yet, as I hope to show, the excess associated with Miranda in her performances is often deliberately artificial, creating an opportunity for audiences to simultaneously give in to their overwhelming abundance and to recognize the excess as a constructed fantasy-and in both ways with Miranda in charge as an active, vibrant figure.

What follows is an analysis of these opening moments in Miranda's first three Fox musicals_-Down Argentine Way (1940), That Night in Rio, and Weekend in Havana (1941) (along with some discussion of the numbers from a later film, The Gang's All Here [1943]). After describing these numbers in some detail, I hope to show how, by both visual and auditory means, the presentation of Miranda creates an excessive fantasy realm that, while fully exploiting a sense of non-U.S. exoticism, also invites the spectator to submit to the maternal embrace of Miranda’s star presence.

\section{The Numbers}

Down Argentine Way (1940), Miranda's first Hollywood feature, begins with her literally front and center. The opening shot (after the credits) is a medium shot of Miranda, performing "South American Way" all in one take. The bottom of the frame cuts her off just at the midriff, allowing her a bit of movement, although the camera stays stationery and thus she must limit her range of motion. Miranda directs her gaze in a wide variety of directions, including directly out at the camera, as if performing to every row and balcony of the audience. Except for the title phrase, Miranda sings completely in Portuguese-and without English subtitles for U.S. audiences. She is dressed in deep red and gold, both in her 
gown and in her headdress, accented by a many-stranded white bead neckpiece.

Directly behind her is placed a grey archway, and behind that a pink cyclorama. When Miranda completes the song, the shot dissolves to a montage of secondunit footage of Buenos Aires. Only after this montage are characters introduced and the narrative impetus begun.

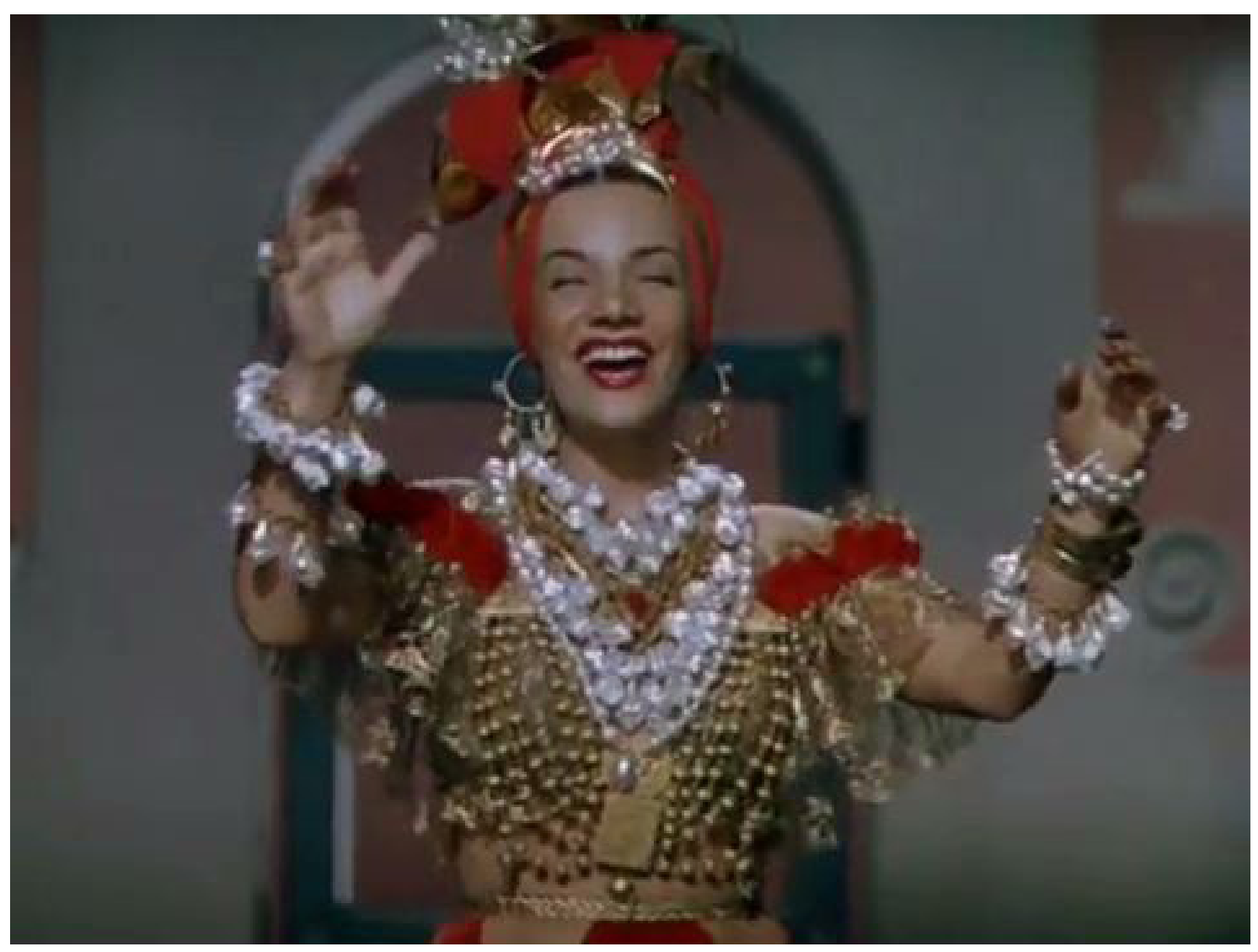

Down Argentine Way (Irving Cummings, 1940)

The opening of That Night in Rio (1941) echoes the start of Down Argentine Way, but expands it from a two-minute song to a five-and-a-half minute production number. The credits are followed by a blatantly artificial backdrop of the Rio coastline (with the Corcovado mountain off in the distance) as fireworks launch into the night sky. This view dissolves to a medium shot of Miranda arched by sparklers in front of her. Unlike the first film, Miranda is surrounded by chorus members who are holding the sparklers. In addition to both male 
and female dancers, Miranda's own Bando da Lua ${ }^{3}$ is seen behind her. Miranda comes forward through the sparklers and begins to sing "Chica Chica Boom Chic" in Portuguese_-again without English subtitles. Although still a medium shot, the camera is a little further back than before, giving Miranda more room to move-and twice the film cuts to a full body shot of her on the front right side to show even more of her dancing. While Miranda performs in front of a cyclorama of Rio at night this time, emphasizing a deep blue, the lights of the city are depicted as giving off a rich pinkish-purple hue. Miranda herself is dressed mainly in silver, although the silver fountain headdress is crowned with green foliage and a variety of yellow, orange and red fruits or beads. If anything, Miranda sings even more directly to the camera than in "South American Way."



That Night in Rio (Irving Cummings, 1941)

As Miranda finishes a chorus of "Chica Chica Boom Chic," the camera pans to the right to reveal an open-top car driving into the scene. In it stands Don Ameche, in a gleaming white naval officer's uniform (sitting behind him are two more like "a gang that serenades" -- under the moon, of course. 
sailors). Ameche sings a greeting to the crowd. It is possible to read a direct address gaze during his speech as well, but his references to "you" are undeniably to Brazilians (both in the diegesis and in the movie theatre audience?). While Ameche seems to have taken over the number, he is only once framed by the camera on his own. Throughout the majority of his vocal solo, he is shown in a two-shot with Miranda (who stands slightly in front of him). As he breaks into a chorus of "Chica Chica Boom Chic," Miranda regularly interrupts him to take over the song - and when she does the camera usually cuts to a one-shot of her.

As they finish this second chorus of the song, the film cuts to a close up of a banda drum being pounded, lit in a vibrant red. The camera tilts slightly to another instrument - a hollow drum being scraped from inside. ${ }^{4}$ The next shot is of a male and female couple swaying to the beat, similarly awash in red. Slowly the camera pulls back to show an entire chorus of similar couples. As the camera does so, the red lighting effect ebbs, increasingly emphasizing the turquoise blue in the women's multi-colored skirts, as well as the matching blue of the men's pants. Furthermore, as the camera pulls back, it reveals that all of this is a nightclub performance-with customers seated at tables on the fringes of the screen. As the chorus continues to dance, the beat of the music switches from a Latin rhythm to U.S. swing. Eventually Miranda re-enters the number, dancing in turn with a number of chorus boys, before Ameche steps in again and the number ends. 


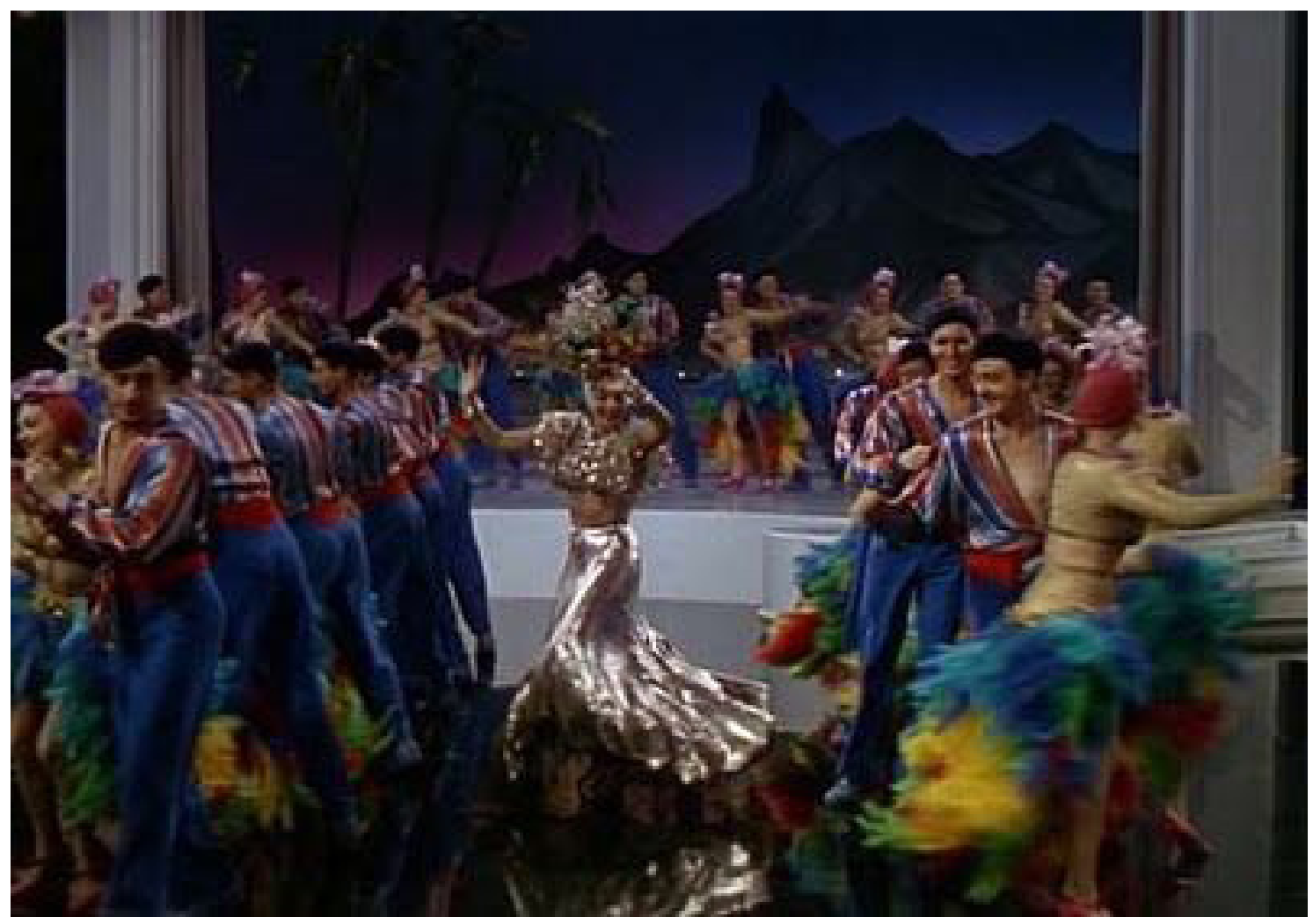

That Night in Rio (Irving Cummings, 1941)

Week-end in Havana (1941) frames its opening number differently. The first shot after the credits is of the Brooklyn Bridge in winter! This shot is followed by three dissolves to various travel posters for Cuba. In each, Cuba as a vacation spot is associated with the feminine. The first is for a cruise liner called the Cuban Queen; the second has a graphic silhouette of a black woman; and the third has a drawing of a white female bathing beauty. This triptych then dissolves to a sidewalk shot of the window display of a travel agency. One assumes this is in New York City, since there is snow falling and the extras who hurry by are in heavy dark overcoats. The camera tracks into the display: a cardboard cut-out of Miranda and the Bando da Lua performing. The camera continues to pull in until it has placed one of the Banda's members in medium close-up. The shot dissolves from the inanimate cut-out to an impressive matching live-action shot of the fellow as he begins to perform. The camera pulls back to show the entire band, accompanied by a trumpet player, aiming their gaze and instruments not at the camera but off-screen to the left. The camera unsurprisingly pans left to 
reveal Miranda. When Miranda is shown, she is in a full shot, but quickly the camera pulls in to the by-now expected medium shot as she sings the title song.

There are also similarities in the visual design. Like Down Argentine Way, Miranda is photographed in front of a pale grey archway (but with the blue background of That Night in Rio rather than the pink of the first film). The color scheme of Miranda's outfit is a blend of the first two films-a combination mainly of red and white. Her top is striped red and white, as is her headdress. The headdress is accentuated with green and yellow foliage, matching a yellow and white neckpiece, as well as some green trim on her top. The skirt has broader stripes of red, white and green with just a few yellow highlights (and two flesh-colored "panel cutouts" on her hips). Finally, as the number ends, the film dissolves to a Cuba travelogue montage, similar to the montage that followed Miranda's opening number in Down Argentine Way, which is finally followed by actual dialogue introducing characters and the crisis that initiates the plot of the film. There are variations from the first two numbers, though. For one, the camera remains mobile, giving Miranda more room to move around as she sings. After she finishes one chorus of the song, the camera cuts to another full shot, allowing her to twirl and move with greater energy, before cutting back to a medium shot as she concludes the number. Also, unlike the other two openings, Miranda now sings completely in English.

\section{Miranda as Visual Abundance}

Much has been said and written about the opulence of Carmen Miranda's image: the colorful costumes, the incredibly high-wedged shoes, the elaborate headdresses, the large necklaces and earrings. Usually, Fox matched Miranda's costuming with an explosion of color and ornateness in the scenic design. All three opening numbers just described emphasize the rich hues (pinks, reds, greens, 
blues) possible with the relatively new process of "three-strip" Technicolor. ${ }^{5}$ Technicolor itself was still rarely used, and the films take full advantage of how the technology registered such deep, oversaturated, almost blushing, colors. In addition, the "Chica Chica Boom Chic" number literally explodes with fireworks to match Miranda's own vibrance. While the camera movement in the three opening numbers is somewhat limited, it increases with each successive film, as if realizing the need for mobility to capture and enhance the spectacle. Possibly the most famous example of such audacious mise-en-scene occurs in "The Lady in the Tutti Frutti Hat" sequence in The Gang's All Here. Conceived by director/ choreographer Busby Berkeley, Miranda performs in the middle of a banana plantation run amok. As chorus girls caper with six-foot tall bananas and threefoot round strawberries creating various kaleidoscopic patterns, the camera lifts, tilts and pivots in any number of ways to increase the delirium. The number ends with Miranda's banana-and-strawberry topper blending into a backdrop of more and more, larger and larger bananas, with the camera pulling farther and farther away until Miranda is practically a speck on the horizon, the hat threatening to spill out of the screen into the viewer's lap.

As the "Tutti Frutti Hat" number indicates, both Miranda's costuming and the art direction associate such visual excess with a sort of natural abundance. All manner of flora seem to proliferate, and Miranda's headdresses often approximate cornucopias of agricultural delights. In the openings for That Night in Rio and Week-end in Havana, for example, a variety of foliage sprouts above her head. While Miranda's outfits were based on the traditions of the Bahian population of Brazil (thus perhaps connecting them to the land), Fox's renditions glamorized their design until they began reaching almost absurd proportions of fertility. As

5. The term "three-strip" refers to the process developed by Technicolor. Three separate negatives were used, each sensitive to a specific color range (red, yellow and blue), that would then be developed and combined into one single strip of film. The process was used from the late 1930s through to the early 1960s, when cheaper (but less vivid and more likely to fade over time) "one-strip" color processes became prevalent. 
ano I número 2

Dossiê such, Miranda often seems to personify a vision of "Mother Earth" displaying her bounty both on her person and extending to the world around her.

But just where this world is is often left vague and amorphous. For example, the space of the "Tutti Frutti Hat" number becomes increasingly surreal and untethered from reality or logic. Even from shot to shot, it becomes hard (if not impossible) for a viewer to create a mental map of where people and things are in relation to each other. In particular, Miranda's introductory numbers are largely undefined and free-floating. Coming directly after the credits, no explanation of where or when these moments are happening is given to the viewer. This is particularly true in the "South American Way" opening to Down Argentine Way. For most U.S. audiences, this was the first time they had seen Mirandaand she is presented sans context. She comes out of nowhere, performs, and then is followed by some footage of Buenos Aires. When characters are finally introduced and dialogue begins, there is no reference to this mysterious female figure. There is not even an indication of what the location that Miranda inhabits is in relation to the ensuing narrative. ${ }^{6}$ What the viewer can see behind her are some archways against a wash of pink-yet the scenery is blatantly artificial (the pink suggests a backdrop rather than an actual sky). Other than a general sense of "Latin-ness," there is no sense of what this place is. The refusal to contextualize the number also places it outside of time. Does this performance happen before the ensuing narrative? Is it going on simultaneous to the events? Or, is it simply outside of temporal considerations? Such mystery was (and may continue to be) accentuated for Anglo viewers by the fact that, except for the title phrase, Miranda sings solely in Portuguese, without subtitles for aide. All such viewers

6. Part of this lack of spatial connection to the rest of the film is because Miranda was quite literally in a separate space from the rest of the cast. Miranda had been hired to do the film, but was still under contract to perform at a nightclub in New York City during the film's shooting schedule. Thus, Fox sent out a camera crew to New York to film her numbers, and Miranda never had any actual contact with anyone else in the picture. "Vital Statistics on 'Down Argentine Way'” via Harry Brand, Director of Publicity (Aug. 22, 1940), 1, Down Argentine Way Production Files, Academy of Motion Picture Arts and Sciences, Margaret Herrick Library. 
can tell is that Miranda knows what she's talking about-and various facial expressions (raised eyebrows, winks of the eye, sly grins) seems to indicate what she knows is pretty intriguing (and, again tied to fertility, potentially sexual). As Shari Roberts argues, and "The knowingness she expresses in this clip indicates her own subjectivity, insinuating that she knows a secret to which the viewer will never have access" (ROBERTS, 1993: 18). It is she who controls this space, not the viewer.

This floating sense of space (and time) continues in the openings to the next two films. Week-end in Havana practically duplicates the amorphousness of Down Argentine Way's opening-even down to the archways in the background (and showing Miranda and the Bando da Lua as cardboard cut-outs before they "spring to life" furthers the sense of being outside of real time and space). The opening moments of That Night in Rio may be more locatable with the Rio coastline in view behind Miranda, yet (again) the artificiality of the view undercuts any sense of stability. If anything, Miranda and company seem to be somehow floating above Rio. It is not until the final moments of the number, as the camera pulls back to reveal the performance as a nightclub act, that the film anchors this space to a particular location and time.

All of these factors (the colorful excess, the associations with fertility, the amorphous permeability of space and time) would appear in the opening to The Gang's All Here. A luxurious, carefully crafted single take starts with a closeup of a male vocalist singing "Brazil" in Portuguese, pulling back to show him standing in the midst of an abstract void dominated by diagonal pattern of what seems to be bamboo. The camera then drifts left to reveal a port of call (again, recognizably artificial), with a ship (labeled as the Brazil) docked at a pier and passengers disembarking. The camera booms up to notice that the ship is also unloading large quantities of fruits and vegetables. As the cargo descends, so to does the camera, until it comes upon-just under the fruit as if it were a 
ano I número 2

Dossiê

headdress-Miranda in close up. She then sings "You Discover You're in New York" (still without an edit), a song that describes various items associated with Latin America showing up in New York City, again emphasizing the haziness of the boundaries. Finally, as with the opening to That Night in Rio, the camera pulls farther and farther back to reveal that this number is actually taking place in a New York City nightclub.

In combining the motifs of excessive fertility with the concerted efforts to show Miranda as even outside the structures of time and space, these numbers arguably create a metaphoric womb (and one could push the analysis farther by linking the prevalence of pinks or reds not just to connotations of "Latin passion" but to the womb). In this lush yet free-floating setting, the viewer is invited to surrender to the wonders and pleasures that the dominant Miranda seems to authorize.

\section{Miranda's Sonorous Envelope}

The womblike ambience of these opening numbers is created not solely by the visual markers. The soundtrack's contribution to the construction of this abundant, amorphous realm may be even more powerful. In musicals, the soundtrack often becomes just as important as the visual track, if not more. While the visual excess of Miranda's numbers may create a sense of spilling over the screen, all soundtracks reach beyond the screen. In her work on film sound, Mary Ann Doane has famously theorized the concept of the sonorous envelope, of how sound is not easily localized "over there" on the screen but inhabits the space of the audience. "The screen is the space where the image is deployed, while the theater as a whole is the space of the deployment of sound" (DOANE, 1986: 338). Sound waves radiate out from speakers and literally surround, touch and reverberate within the body of the filmgoer. This may be more obviously 
true in more recent moviegoing, where film theatres are equipped with surround sound systems enabling various sounds to come from various directions in the auditorium. Doane noted this, asserting that "The spatial dimension which monophonic sound is capable of simulating is that of depth-the apparent source of the sound may be moved forward or backward, but the lateral dimension is lacking due to the fact that there is no sideways spread of reverberation or of ambient noise" (p. 338). Yet, even in the monoaural musicals that Miranda made for Fox, with speakers only in the front of the theatre, the sound would still bounce off the various parts of the building (depending on the individual acoustics) and surround the viewer to a certain extent.

Doane associates this sonorous envelope expressly with the plenitude of the womb, of a return to the Imaginary.

The voice also traces the forms of unity and separation between bodies. The mother's soothing voice, in a particular cultural context, is a major component of the 'sonorous envelope' which surrounds the child and is the first model of auditory pleasure....The imaginary fusion of the child with the mother is supported by the recognition of common traits characterizing the different voices and, more particularly, of their potential for harmony. According to Rosolato, the voice in music makes appeal to the nostalgia for such an imaginary cohesion" (DOANE, 1986: 343).

As the above quote indicates, many scholars have noted how music more strongly emphasizes the ability of sound to reach across and erase boundaries. Adrienne McLean argues that singing has the ability "to foster... a sense of... community between listener and performer" (MCLEAN, 2004: 125). Physicist Stephen Handel, examining the psychophysics of music, also finds that "My sense is that I am part of my auditory world but I am looking into my visual world" (WILLIAMS, 1989: 547). 
Just as the visual design of the opening numbers in these films present Miranda as the central figure through which such plenitude seemingly flows, the sound design privileges Miranda's voice as the maternal author of auditory excess to which the filmgoer must surrender. As already pointed out, throughout Miranda's career in Hollywood, her songs in Portuguese were never translated for U.S. viewers, leaving them in the dark as to her meaning or intent. In a way, this mirrors how infants respond to their mother's voice without actually comprehending what is being said. Yet, Miranda's performances are never forbidding or imposing; rather, they are consistently inviting and welcomingdrawing the audience towards her, much as a mother uses intonation to soothe a child not yet capable of understanding individual words. Indeed the lyrics of Miranda's songs often would near the level of "baby-talk," with nonsense title "Chica Chica Boom Chic" serving as only one example.7

The rhythmic pulse of Miranda's music strengthens this sense of a maternal sonorous envelope, and pushes it to an even earlier stage between mother/child: the unborn child's connection to the mother's heartbeat. Within the womb, the sound of the mother's heart surrounds the fetus, at a period when boundaries between self and Other are incredibly hard to distinguish. Such sounds are not just heard, it must be noted, but felt within the body of the fetus as well. All music is based on rhythmic patterns, of course, but the Latin beats that accompany Miranda emphasize the percussive (the close-ups of the drums in "Chica Chica Boom Chic" and the focus on the Bando da Lua drummer at the start of "Week-end in Havana"). Miranda and others helped create a Latin music craze within the States during the early 1940s, popularized in part because of the sense of the rhythm of the mambo and conga ${ }^{8}$ dances "entering your body" and "stirring your blood."

7. Others might include "I Yi Yi Yi Yi," also from That Night in Rio, and the playful rendition of "Chattanooga Choo Choo," which she sings in a mish-mash of both Portuguese and English in Springtime in the Rockies (1942) in order to play with the alliteration-and ending the song by sneezing!

8. And the -- Brazilian -- samba, Miranda's specialty. 
The mother's voice also reverberates around the unborn child as well, an experience possibly reinvoked through the practice of close-miked sound for classical Hollywood musical numbers. For musicals, performers record their singing during pre-production in sound booths with perfect acoustics and the microphones placed in an optimal position to capture their voices. During shooting, the performer then lip-syncs to the already recorded track. Yet, the sound in the dialogue sequences are recorded "on set," providing a different auditory environment, with the microphones set slightly farther away from the performers (so as not to be seen on camera). Thus, within musicals, there is often a recognizable shift in tone and timber in voices as the soundtrack shifts from diegetic speech to pre-recorded singing, a shift that Alan Williams describes as "thoroughly noticed and felt" (WILLIAMS, 1981: 156). The process of pre-recording has the effect of somewhat disembodying voices during musical numbers. The sense of place (white noise, the voice's reverberation within the space) suddenly is eliminated, and the voice suddenly takes on a greater omni-presence. Similar to how Alan Williams and others have analyzed close-miked musical performance, Linda Williams, in her analysis of sound design in pornographic films, describes how non-diegetic "sounds of pleasure" during sex scenes lend a certain ambiguity as to the performer's position in space (a sense of "spacelessness") as well as a certain intensification of intimacy (WILLIAMS, 1989: 124). Thus, the excess of visual plenitude and free-floating space is accompanied by an equally intense sense of interconnectivity and spacelessness in what is heard. Together, these opening numbers arguably present Miranda as a benevolent, omnipresent, omniscient maternal source of bounty and gratification. 


\section{Signifying the Imaginary}

Of course, it is vital to recognize that Miranda's numbers (and cinema in general) are not a return to the Imaginary, but a Symbolic representation of it created by dominant U.S. patriarchal capitalist ideology (thus ironically working to more fully suture the subject into the Symbolic realm rather than the Imaginary). As such, the maternal plenitude of Miranda is momentary and not without an attempted agenda. It takes very little effort to argue that Miranda is presented in these films in a manner that asserts patriarchal domination through the objectification of women, and that they similarly assert U.S. superiority by commodifying Latin America and its cultures. Shari Roberts points out that "By trading negative 'lazy greaseball' stereotypes for positive 'happy children' stereotypes, the Fox Latin American musicals clearly did not come close to escaping racist representation" (ROBERTS, 1993: 10). Further, she links issues of U.S. imperialism to putting Miranda on sexual display: "Miranda becomes the image of an overflowing cornucopia of South American products, ripe, ready, and eager for picking by North American consumers" (p. 14).

All of the numbers described are also plainly manufactured. Rather than placing Miranda on location in some Latin American locale, the films construct obviously artificial environments, such as the archway backdrops, or the painted overview of the Rio coastline. The opening to Week-end in Havana practically beats the viewer over the head with a sense of artifice by introducing Miranda and the Bando da Lua as cardboard cutouts. Most memorably, no audience member would believe that those are really 6-foot-high bananas in the "Tutti Frutti Hat" number. The representations of fertility, sensuality, and exotic Otherness are thus deliberate constructions.

Certain audiences at the time criticized these films and Miranda precisely for these reasons. When she returned to Brazil in 1940 for a concert tour, Brazilian newspapers reported crowds booing and whistling to indicate their displeasure 
with her work in Hollywood. Reviews of her performances in Brazil claimed that her voice and style had changed - that she had become Americanized (WILLIAMS, 1989: 106-107). Clearly, a number of Brazilians recognized the political ramifications of presenting Miranda as a metaphor for maternal plenitude divorced from the complex materiality of the nation's cultural heritage.

Further emphasizing how the films work to reinscribe the Symbolic, the freefloating nature of the opening numbers and of Miranda herself is inevitably pulled back into the narrative diegesis. As noted before, the opening numbers to That Night in Rio and The Gang's All Here eventually reveal themselves to be elaborate night-club performances—with the latter even unveiling that the setting is New York City. Although more than a half hour goes by after Miranda sings "South American Way" in Down Argentine Way, Betty Grable's lead character eventually goes to a Buenos Aires nightclub where she (and the viewer) find out that Miranda is performing there behind the same backdrop of the opening sequence. Just as there is an attempt to finally locate these spaces, Miranda is often given a character name (Rosita or Conchita) to more fully tie her to the diegesis. Within these narratives, Miranda is not the all-powerful dominating presence-rather the plots work to minimize her as the third wheel in a romantic triangle or simply some comic relief from the more important star leads. In Down Argentine Way, she is relegated to merely a cameo performance. In this way, the films work to contain the excess that explodes at the start.

From a psychoanalytic standpoint, such strategies may work to contain the sense of threat raised by the image of Miranda in these opening moments-the female as reminder of castration. Lacan asserts that Freud's concept of castration anxiety (which is initiated with the recognition of sexual difference) is itself a harbinger of entrance into the Symbolic-possibly the strongest example of an awareness of lack. Thus, the efforts to explain Miranda, to minimize her, to literally put her in her place could be seen as the attempts to assert patriarchal power over Miranda's image and disavow the threat of castration. 
Yet, the obviousness of the construction of Miranda's image and her environment complicate this assessment. In highlighting the artifice of these numbers, the filmmakers create a structure that allows audiences to recognize these constructs as constructs, rather than regarding them as somehow natural or true. The effort to disavow phallic lack reaches a level of high absurdity when it resorts to waving giant plastic bananas around. If they, and other aspects of these numbers-including Miranda herself, are meant to be phallic substitutes, their blatant artificiality would undercut their effectiveness.

Similarly, the sound design in these numbers often exposes their construction. Mary Ann Doane argues that filmic sound tries to efface its construction in a number of ways. Primarily, voices are grounded to a particular individual. Yet, "Just as the voice must be anchored by a given body, the body must be anchored in a given space. The phantasmatic visual space which the film constructs is supplemented by techniques designed to spatialize the voice, to localize it, give it depth, and thus lend to the characters the consistency of the real" (DOANE, 1986: 337). She further argues, though, that various stylistic decisions can impair this effacement. For example, "The dangers of post-synchronization and looping stem from the fact that the voice is disengaged from its "proper' space" (p. 337). Also, "If a character looks at and speaks to the spectator, this constitutes an acknowledgment that the character is seen and heard in a radically different space and is therefore generally read as transgressive"(p. 340). Both of these methods are used —and often heavily emphasized—in all of these performances by Miranda, actively celebrating their artifice.

I would argue that the subject position created by these opening numbers (and the "Tutti Frutti Hat" sequence) does involve fetishization and disavowal, but in a different, non-phallic manner. Using theories of masochistic pleasure taken from Gilles Deleuze (rather than the sadistic pleasures of control espoused by Freud, Lacan and Metz), feminist film scholar Gaylen Studlar theorizes that 
the sense of lack associated with the Symbolic is initially due to separation from the mother, not fear of castration, and that "pleasure does not involve mastery of the female but submission to her"(STUDLAR, 1992: 782). This re-consideration does not then claim that such submission is unproblematic to the subject. Rather, "the promise of blissful reincorporation into the mother's body and re-fusion of the child's narcissistic ego with the mother as ideal ego is also a threat"(p. 780). Thus, there is an ambivalence to fully giving over, a forever forestalling of reunion.

Miranda's numbers in these films seem more strongly a celebration of the maternal rather than the phallic-and reactions from audiences then and now often attempts to disavow their willingness to surrender to the excess of Miranda. As Roberts notes about contemporary media discussion in the U.S. about Miranda:

\footnotetext{
The joy reviewers articulate about Miranda's lack of English stems partly from the illusion of masculine and American superiority but also from an enthusiasm for a freedom within or without language, the freedom allowed by songs when the listener has 'no clue to their meaning' - the freedom experienced through the recognition of the artifice, as opposed to the essence, of social definitions of ethnicity and femininity. (ROBERTS, 1993: 15)
}

Such simultaneous dual reactions mirror Doane's theorizations that the human voice functions as "an interface of imaginary and symbolic, pulling at once toward the signifying organization of language and its reduction of the range of vocal sounds to those it binds and codifies, and toward original and imaginary attachments" (DOANE, 1986: 343). Similarly, the almost immediate and (to this date) ongoing camp appeal of Miranda's persona within gay male culture also functions to simultaneously keep an ironic distance from and yet revel in her spectacular beneficent maternal excess. As Steven Cohan has argued 
in analyzing musicals made at MGM around this same period, contemporary heterosexual audiences seemed to recognize the camp appeal of musicalseven if they may not have known the term "camp" itself (or its subcultural aspects). ${ }^{9}$ Awareness of the artifice (in the mise-en-scene, in the sound design, and in Miranda's own performativity) has historically allowed multiple viewers the ability to recognize how the Imaginary is being constructed, and enjoying it nonetheless_-of laughing at the excess of these opening numbers, yet laughing at one's self for giving over to it.

And, even as the numbers create a position for viewers to acknowledge the artifice, Miranda still seems to remain the powerful central force. For it is she who is presented as authorizing the artifice-bestowing not only the artificial abundance but also the wink of the eye that shows she is complicit in the construction. After all, Miranda is the one who concocted her fashion style, not Hollywood; it is Miranda looking directly at the camera with a sly grin. Miranda's persona in these opening numbers may be an elaborately produced version of maternal plenitude, yet Miranda is shown as not only in on the joke, but the one who seems to be telling it to increase our pleasure, and envelop us in her embrace all the more thoroughly.

\section{Conclusion}

When Betty Grable's character in Down Argentine Way sits to watch the (finally) diegetically-included Carmen Miranda perform at a Buenos Aires nightclub, Miranda enters to sing one of her most popular hits, "Mamãe eu quero" As with all of Miranda's numbers, the Portuguese lyrics are never subtitled in English, keeping most U.S. viewers from understanding what 
she is singing about. Yet, U.S. audiences seemed to at least catch the titleand "Mamãe eu quero" was the song most Miranda impersonators (male or female) seemed to use when performing. ${ }^{10}$ If nothing else, the word "mamãe" resonated —and, if the individual had some rudimentary knowledge of language, possibly realizing that "mamãe" was being told that "I want something"...or simply that "I want my mamãe!"

The song, and Miranda's performance of it, encapsulate this argument. It is quite possible to read the number as infantilizing Miranda, of positioning her as subordinate to the powerful controlling gaze of U.S. patriarchal capitalism. Yet, it is also possible to see the song as Miranda's acknowledgement of the subject's own sense of lack ("I want...") and sense of separation from and dependence upon the mother. And, every time Miranda shows up on screen to perform, the viewer can-for a fleeting moment that is itself complexly constructed and understood_-bridge that gap and fall into her sublime maternal clasp. "Mamãe eu quero — oh, oh..." 


\section{Bibliography}

COHAN, Steven. Incongruous Entertainment: Camp, Cultural Value, and the MGM Musical.

Durham: Duke University Press, 2005.

DOANE, Mary Ann. "The Voice in the Cinema: The Articulation of Body and Space," in Narrative, Apparatus, Ideology, Philip Rosen, ed. New York: Columbia University Press, 1986.

GIL-MONTERO, Martha. Brazilian Bombshell: The Biography of Carmen Miranda. New York: Donald I. Fine, 1989.

HANDEL, Stephen. Listening: An Introduction to the Perception of Auditory Events. Cambridge: MIT Press, 1989.

HECHTLINGER, Dorothy. "Rings on Her Fingers" Conference with Mr. Zanuck on 1st Draft Continuity (Sept. 26 - 30, 1940), 3, University of Southern California Fox Script Collection.

LACAN, Jacques. Ecrits: A Selection. Trans. Alan Sheridan. New York: Norton, 1977.

LOPEZ, Ana M. “Are All Latins from Manhattan?: Hollywood, Ethnicity and Cultural Colonialism," Unspeakable Images: Ethnicity and the American Cinema, Lester D. Freidman, ed. Urbana: University of Illinois Press, 1991.

MCLEAN, Adrienne. Being Rita Hayworth: Labor, Identity, and Hollywood Stardom. New Brunswick: Rutgers University Press, 2004.

METZ, Christian. The Imaginary Signifier: Psychoanalysis and the Cinema. Trans. Celia Britton, Annwyl Williams, Ben Brewster, Alfred Guzzetti. Bloomington: Indiana University Press, 1982.

ROBERTS, Shari. "The Lady in the Tutti-Frutti Hat': Carmen Miranda, a Spectacle of Ethnicity," Cinema Journal 32, no. 3 [Spring 1993], 18.

ROSALATO, Guy. "La Voix: entre corps et langage," Revue francaise de psychoanalyse (January 1974), 38:83, 82.

SHOHAT, Ella \& Stam, Robert. Unthinking Eurocentrism: Multiculturalism and the Media. New York: Routledge, 1994. 
STUDLAR, Gaylen. "Masochism and the Perverse Pleasures of the Cinema," Film Theory and Criticism, 4th ed., eds. Gerald Mast, Marshall Cohen and Leo Braudy. Oxford: Oxford University Press, 1992.

"That Night in Rio" (Variety, Mar. 7, 1941), That Night in Rio Production Files, Academy of Motion Picture Arts and Sciences, Margaret Herrick Library.

Vital Statistics on 'Down Argentine Way'” via Harry Brand, Director of Publicity (Aug. 22, 1940), 1, Down Argentine Way Production Files, Academy of Motion Picture Arts and Sciences, Margaret Herrick Library.

WILLIAMS, Alan. "The Musical Film and Recorded Popular Music," in Rick Altman, ed., Genre: The Musical. London: British Film Institute, 1981.

WILLIAMS, Linda. Hard Core. Berkeley: University of California Press, 1989. 